\title{
ALTERNATIF MATERIAL BARU PENGOLAHAN DINDING BANGUNAN BERBAHAN ABU BATU DI KELURAHAN TELAGA BIRU KECAMATAN BANJARMASIN BARAT KOTA BANJARMASIN
}

\author{
Fitria Handayani, Akhmad Gazali, Ruliana Febrianty, dan Muhammad Saukani \\ Fakultas Teknik, Universitas Islam Kalimantan \\ Email: fitria.ftsunika@gmail.com; akhmadgazali51@gmail.com; \\ saukani@uniska-bjm.com; rullyanafebrianti@yahoo.com
}

\begin{abstract}
ABSTRAK
Abu batu adalah hasil dari pengolahan batu pecah dengan menggunakan stone crusher. Abu batu saat ini merupakan bahan hasil sampingan dalam industri pemecahan batu yang jumlahnya tidak sedikit. Abu batu diupayakan pemanfaatannya sebagai bahan pengganti pasir karena harganya lebih murah jika dibandingkan dengan pasir. Abu batu dapat digunakan sebagai bahan utama pembuat beton, batako, dan perekat paving maupun sebagai pengisi (filler yang mengisi rongga-rongga kecil pada beton dan membuat beton semakin padat sehingga dapat meningkatkan mutu beton). Penggunaan abu batu dalam industri beton bisa mencapai lebih dari $50 \%$ terutama untuk pembuatan conblock, batako, dan gorong-gorong. Manfaat lain dari abu batu yaitu mampu mengikat material lebih baik, menghemat penggunaan semen, mempercepat produksi batako/beton, hamparan lapisan dasar pada pemasangan paving blok dan memperkecil pori conblock.
\end{abstract}

Kata Kunci : Abu batu, dinding bangunan, batako, batu pecah

\section{PENDAHULUAN}

\section{Analisa Situasi}

Kondisi tanah kota Banjarmasin pada umumnya merupakan tanah rawa dan tanah lunak sehingga sangat sulit mendapatkan material pasir yang menyebabkan harga jualnya menjadi tinggi. Sedangkan pembangunan kota ini semakin pesat di masa yang akan datang mengingat Banjarmasin termasuk kota besar dan terdapat pusat perbelanjaan yang cukup banyak di Kalimantan. Sehingga tidak heran semakin tahun pembangunan ruko-ruko dan komplek perumahan semakin meningkat.

Pembangunan ruko maupun rumah tersebut tidak lepas dari material pasir sebagai campuran semen, baik sebagai perekat antar dinding maupun untuk jalan lingkungan berupa paving block. Namun disayangkan semakin hari harga material bangunan semakin tinggi. Hal ini menyebabkan adanya pengurangan takaran material pasir maupun semen dalam pengerjaan kontruksi yang tidak dibarengi dengan peningkatan mutu bahan sehingga berdampak pada kerusakan dinding 
bangunan yaitu menyebabkan keretakan dinding bangunan ruko.

\section{Identifikasi dan Perumusan Masalah}

Abu batu adalah hasil dari pengolahan batu pecah dengan menggunakan stone crusher. Abu batu saat ini merupakan bahan hasil sampingan dalam industri pemecahan batu yang jumlahnya tidak sedikit. Abu batu diupayakan pemanfaatannya sebagai bahan pengganti pasir karena harganya lebih murah jika dibandingkan dengan pasir.

Abu batu dapat digunakan sebagai bahan utama pembuat beton, batako, dan perekat paving maupun sebagai pengisi (filler yang mengisi ronggarongga kecil pada beton dan membuat beton semakin padat sehingga dapat meningkatkan mutu beton). Penggunaan abu batu dalam industri beton bisa mencapai lebih dari $50 \%$ terutama untuk pembuatan conblock, batako, dan gorong-gorong. Manfaat lain dari abu batu yaitu mampu mengikat material lebih baik, menghemat penggunaan semen, mempercepat produksi batako/beton, hamparan lapisan dasar pada pemasangan paving blok dan memperkecil pori conblock.

\section{Perumusan Masalah}

Meskipun bahan abu batu memiliki banyak keunggulan, namun hanya sedikit sekali masyarakat yang mengetahui manfaat abu batu untuk material bahan bangunan sehingga menjadikan industri kecil pengolah abu batu pada akhirnya tutup produksi.Perumusan

masalahdaripengolahan abu batu menjadi bahan bangunan antara lain:

a. Seberapa kuat material berbahan abu batu menahan beban dan mencegah terjadinya keretakan dibandingkan dengan material berbahan lainnya?

b. Berapabesar selisih harga material pasir jika dibandingkan dengan bahan abu batu?

c. Seberapa besar abu batu mampu menghemat biaya kontruksi bangunan?

\section{Solusi Permasalahan}

Solusi permasalahan pengabdian pada masyarakat ini adalah untuk memberikan pengetahuan kepada masyarakat mengenai:

a. Mencampur material dengan bahan dari abu batu saat mendirikan suatu bangunan yang memerlukan banyak pasir dan semen dengan tujuan menghemat pembelian material.

b. Campuran material abu batu dengan takaran yang sesuai (bahkan hingga 
50\%) agar menghasilkan bangunan yang kuat tetapi murah biayanya.

c. Limbah abu batu sebagai campuran bahan bangunan sangat membantu meningkatkan ekonomi masyarakat kecil yang bekerja dibidang itu.

\section{KHALAYAK SASARAN}

Sasaran utama kegiatan ini adalah warga yang perumahannya berada di tanah lunak, tokoh masyarakat, pemuda dan ulama masyarakat Kelurahan Telaga Biru Kecamatan Banjarmasin Barat Kota Banjarmasin. Karena mereka dapat memperluas hasil kegiatan pada anggota sasaran lainnya.

\section{METODE PELAKSANAAN KEGIATAN}

Pelaksanaan program sosialisasi tentang penyuluhan alternative material baru pengolahan dinding bangunan berbahan abu batu di kelurahan Telaga Biru Kecamatan Banjarmasin Barat di kota Banjarmasin akan dilakukan dengan metode ceramah dan Tanya Jawab.

\section{Tahap Persiapan}

Tahap persiapan dalam kegiatan pengabdian ini adalah penyusunan pre planning. Persiapan media berupa power point dengan materi penyuluhan mengenai manfaat material bangunan yang mengandung abu batu. Langkah pertama adalah membuat kontrak, waktu dan tempat penyuluhan dengan lurah dan perangkat setempat.

2. Tahap Perizinan

Tahap Perizinan terdiri dari pengajuan izin, pembuatan kontrak, penyesuaian waktu dan lokasi penyuluhan dengan mitra.

3. Tahap Pelaksanaan

Kegiatan penyuluhan ini dilakukan dengan mengumpulkan warga dengan koordinasi lurah. Materi akan diberikan kepada para peserta berupa buku dan gambar-gambar. Di akhir pemberian ceramah peserta dipersilahkan diberi kesempatan untuk melakukan Tanya jawab dengan narasumber. Diharapkan dari sini maka para peserta akan mengerti dan dapat memberkan masukan kepada mereka dalam memilih material berbahan abu batu untuk dinding rumah maupun pemakaian paving block.

4. Tahap Pengambilan Kesimpulan

Tahap akhir untuk mengevaluasi segala kegiatan PKMS untuk mendapatkan kesimpulan positif agar 
program dilaksanakan

berkesinambungan.

HASIL

PELAKSANAAN

\section{KEGIATAN}

Kegiatan penyuluhan Alternatif Material Baru Pengolahan Dinding Bangunan Berbahan Abu Batu Di Kelurahan Telaga Biru Kecamatan Banjarmasin Barat Kota Banjarmasin dilaksanakan selama satu hari pada tanggal hari Minggu, 1 Desember 2019. Kegiatan penyuluhan dilakukan dengan cara mengumpulkan warga Komplek Simpang Wildan Sari 7A No. 70 RT.01 Kelurahan Telaga Biru Banjarmasin Barat sudah meminta izin kepada ketua RT setempat.

Kegiatan penyuluhan diawali dengan pemberian informasi tentang mencampur material dengan bahan dari abu batu saat mendirikan suatu bangunan yang memerlukan banyak pasir dan semen dengan tujuan menghemat pembelian material, campuran material abu batu dengan takaran yang sesuai (bahkan hingga $50 \%$ ) agar menghasilkan bangunan yang kuat tetapi murah biayanya sebagai alternatif pengganti bata merah dan perekat semen. Kemudian dilanjutkan dengan tanya jawab tentang seberapa kuat material berbahan abu batu menahan beban dan mencegah terjadinya keretakan dibandingkan dengan material berbahan lainnya?, berapa besar selisih harga material pasir jika dibandingkan dengan bahan abu batu?, seberapa besar abu batu mampu menghemat biaya kontruksi bangunan khususnya untuk daerah kelurahan Telaga Biru.

Kesuksesan pelaksanaan pengabdian yang telah dilakukan dapat dilihat motivasi warga yang hadir mengikuti acara serta pencapaian tujuan kegiatan pengabdian yang telah dilaksanakan. Secara umum tujuan kegiatan pengabdian yang telah ditetapkan sebelumnya dapat dikatakan berjalan dengan baik. Penjelasan pencapaian tujuan kegiatan ini yaitu:

1. Pada umumnya peserta penyuluhan telah memahami. Hal ini dapat dilihat dari antusiasme para peserta saat kegiatan diskusi dan tanya jawab mengenai Material Baru Pengolahan Dinding Bangunan Berbahan Abu Batu

2. Para peserta telah memahami Alternatif Material Baru Pengolahan Dinding Bangunan Berbahan Abu Batu. Pengabdian masyarakat yang telah dilakukan juga memberikan 
hasil yang cukup bermanfaat bagi semua pihak yang terkait dalam kegiatan tersebut. Berikut diuraiakan beberapa hasil yang telah dicapai, baik oleh peserta pelatihan maupun tim pelaksana.

1. Peserta penyuluhan

a. Peserta penyuluhan memiliki pengetahuan dalam memilih material yang tepat untuk dinding bangunan, misalnya, batako berbahan abu batu, campuran abu batu dan semen sebagai perekat paving block.

b. Peserta penyuluhan mengetahui Persentase campuran material agar menghasilkan bangunan yang kuat tetapi murah.

c. Membangun kreatifitas Peserta penyuluhan dalam memanfaatkan limbah sehingga membuka lapangan kerja Sehingga limbah abu batu tidak terbuang percuma.

2. Tim Pelaksana

a. Tim pelaksana mendapatkan pengalaman dalam praktek kegiatan pelatihan dan peningkatan keahlian di bidang bahan konstruksi bangunan

b. Tim pelaksana menjalin hubungan yang saling menguntungkan dengan warga kelurahan Telaga
Biru untuk meningkatkan pengetahuan tentang material baru pengolahan dinding bangunan berbahan abu batu.
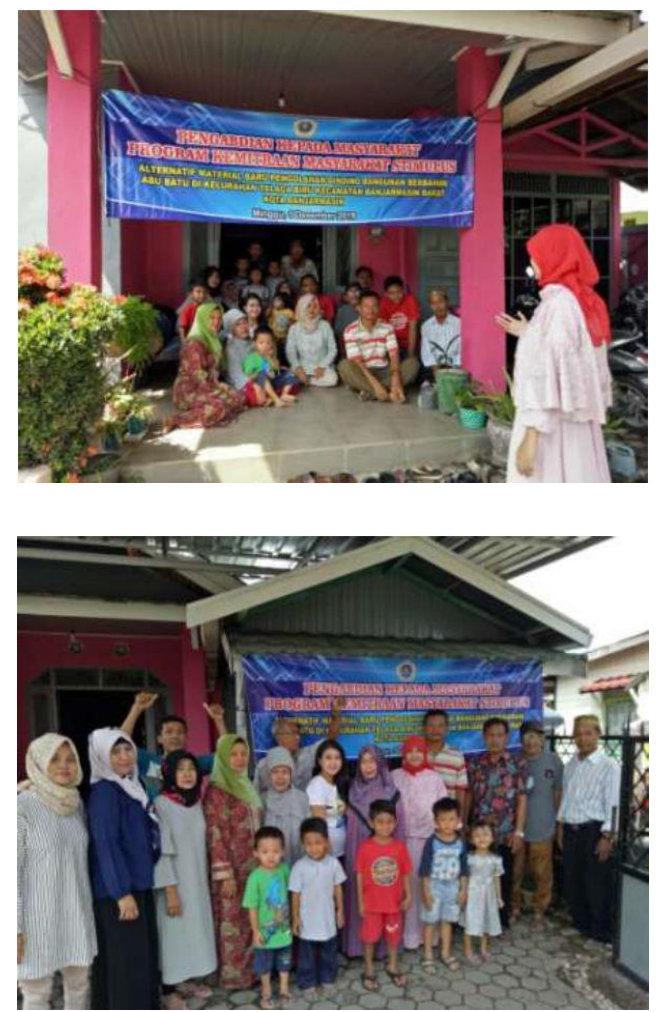

\section{KESIMPULAN}

Dari pelaksanaan kegiatan penyuluhan Alternatif Material Baru Pengolahan Dinding Bangunan Berbahan Abu Batu Di Kelurahan Telaga Biru Kecamatan Banjarmasin Barat Kota Banjarmasin, diperoleh beberapa kesimpulan antara lain sebagai berikut:

1. Bertambahnya kesadaran dan wawasan warga masyarakat tentang alternatif material baru pengolahan dinding bangunan berbahan abu batu 
sebagai alternatif pengganti material pasir yang semakin mahal harganya dan sulit didapat.

2. Mendapatkan pengetahuan ukuran takaran ideal abu batu agar mendapatkan bangunan yang kuat namun murah

3. Limbah abu batu dapat meningkatkan pendapatan masyarakat jika terampil mengolahnya.

\section{DAFTAR PUSTAKA}

Amesta, Usfi. 2015. Pemanfaatan Abu Batu sebagai Bahan Campuran Paving Block dengan Tinjauan Kualitas dan Efisiensi Biaya Produksi. Skripsi, Program Studi Pendidikan Teknik Bangunan, Universitas Negeri Malang.

Hadi, Tjokro. 2012. Manfaat Abu Batu Limbah Stone Crusher sebagai Bahan Bangunan di Kota Rembang.Jurnal Teknis Volume 7 No. 1

Kurnyawan, Didik. 2014. Pengaruh Abu Batu sebagai pengganti Pasir pada Pembuatan Beton. Skripsi, Program Studi Teknik Sipil, Universitas Jember.
Mariana, dkk. 2018. Penerapan Teknologi Pembuatan Trikompos di Desa Sungai Bokor Kalimantan Selatan. Jurnal Al Ikhlas Volume 4 Nomor 1, Opktober 2018

Nursyam, dkk. 2018. Hibah Bina Desa Penerapan Teknologi Pengolahan enceng gondok sebagai Pakan Ternak dan industri Kerajinan Rumah Tangga di Kelurahan Lempake. Jurnal Al Ikhlas Volume 4 Nomor 1, Opktober 2018

Prayogo, H.D. 2017. Analisa Kuat Tekan Paving Blok dengan Abu Batu sebagai Bahan Tambah. Skripsi, Program Studi Teknik Sipil, Universitas Muhammadiyah Purwokerto.

Puspasari , Nirwana. Pengaruh Penggunaan Abu Batu Pecah dan Portland cemment sebagai Filler terhadap Stabilitas dengan Metode Marsall. Jurnal Teknik Sipil Volume 2 No.1

Putra, A. 2015. Perbandingan Filler Pasir Laut dengan Abu Batu pada Campuran Panas ASPHALT Trade Binder untuk Perkerasan Lentur dengan Lalu Lintas Tinggi. Jurnal Bentang Vol.3 No.2

Widodo, Slamet. 2003. Pemanfaatan Limbah Abu Batu sebagai Bahan Pengisi dalam ProduksiSelfCompacting Concrete. Journal of Research of National of Standard and

Technology 